\title{
Analysis of Direct Private Investment: The Case of Bachelor's Level in Community College
}

\author{
- Min Raj Paudel \\ Lecturer, Central Department of Education, TU
}

\begin{abstract}
The costs spent by students or parents while attaining education are called the direct private costs which are usually placed outside and inside the domain of educational institutions. The present study is a quantitative survey that aims to conduct a comparative analysis of institutional and noninstitutional direct private costs. Furthermore, it tries to find the size of institutional and non-institutional direct private costs at Bachelor's level education in Nepal. For these purposes, I have selected a community based college from Kathmandu valley purposively and 90 students of Bachelor's level (30 each from the faculty of humanities, education and management) were selected using simple random sampling technique. The findings of the study reveal that the average college related institutional unit cost per student was Rs. 24730.57, university related institutional cost was Rs. 5982.23; and total annual institutional unit cost was Rs. 30712.80. Likewise, it was found that a student has expensed Rs. 46411.63 as non-institutional direct private cost in a year. Total annual average direct private cost of education (institutional plus non-institutional) was Rs. 77124.43 at Bachelor's level of community based college in the capital city of Nepal.
\end{abstract}

Keywords/terms: Institutional cost, non-institutional cost, direct private investment, Bachelor's level, descriptive method

\section{Introduction}

The use of time and money spent on education is called investment in education. Employment and better income in the future are the main incentives to postpone the present consumption for investment in education. For many people, higher level of education is associated with better chances to get a good job in the labor market (Ismail and others, 2016, pp. 25-26). Therefore, students or parents seem to be ready to invest time and money in higher education (Lugaz and Grauwe, 2016, p. 58-62). Educational investment is known as educational cost, which refers to the amount spent on 
education by the government as well as individual students' parents during the academic year (Khandagale and Pandya, 2014, p. 42).

Educational cost is basically divided into two groups: Social costs and private costs. Social cost is expended by the school/college on educational inputs. It is usually divided into two categories - which include the recurrent and capital costs for accounting purposes. Recurrent cost is expended within a year. It consists of personnel cost like salaries, employment benefits and supplementary benefits paid to teachers, college administrators and other college staffs, and non-personnel costs like the cost of instructional materials, teaching aids, college supplies, minor repair or regular maintenance, utilities, and student welfare (Tsang, 1995, p. 393-94). Capital costs are the expenditures on durable inputs such as furniture, equipment and buildings which can be used for a very long period of time if well maintained (Babalolaj, 1995, p. 45).

Likewise, education is both a private and social investment which contributes to economic development and raises the income of the poor (Akpotu, 2008, p. 27-28). Private cost is defined as that part of investment in education which is made either by the student or parent or both. Private cost on education can be divided into direct and indirect types. Direct private cost relates to the total expenditure incurred by the households towards the education of their children. It includes the expenditure directly related to instruction - such as the fee and non-fee component of education (ibid., p. 28-29).

On the other hand, indirect cost includes all money expenditure on different items spent by the student. It is the expense that can be separately identified and charged as part of the cost of a product, service, or department. Direct cost typically includes items such as instructional and other programme materials, fuel, oil and repairs of vehicles used for home to school transportation, centralized data processing services, in-house equipment repairs, field trips, expenditure on tuition fees, other fees and charges, purchase of books, stationerstationery, uniforms, hostel expenses and transport (Bray, 1999, p. 67). Likewise, indirect private cost refers to the student's time spent in an educational institution. The cost of student's time which could have been utilized in an alternative way (Psacharopoulos and Woodhall, 1995, p. 169) is here referred to as indirect cost of education. 
All sociologists, educationalists and economists have univocally agreed that social cost of education is a backbone for educational, social and economic change and development of a nation. It is true because education provides skillful and capable human resources for market which finds out, excavates and discovers new goods and services to facilitate human beings. In the case of Nepal, the colleges offering higher education is classified into three categories on the basis of investment ownership: Public colleges, community based colleges and private colleges. Government of Nepal does not invest in community based colleges; but University Grants Commission has invested through the quality assurance and accreditation (QAA) program. There is direct investment of community in these types of colleges; and likewise, donors and donor agencies are also investing. The main income source of these colleges is students' fee; and they are not profit oriented. These colleges do not have their own curriculum and are affiliated to different universities. In the case of Nepal, it is said that cost of education in these public colleges is comparatively high. In this context, the study is seeking to answer the research questions regarding the size of institutional direct private cost of education as well as the size of non-institutional direct private cost of education at Bachelor's level in the colleges.

\section{Objectives of the study}

Based on research questions, the following objectives were formulated for the study:

(a) To carry out comparative analysis of institutional and noninstitutional direct private cost spent on education at Bachelor's level.

(b) To find out the size of institutional and non-institutional direct private cost in Bachelor's level.

\section{Rationale for the study}

In this era of privatization and resulting commercialization of education at all levels, it is paramount to analyze the cost of education incurred to students or their parents. There is a public perception which holds the assumption that the higher one pays the amount of fees, the better is it likely to be their education and thereby, ultimately their academic achievement. This perception becomes more pronounced in the case of self-financed colleges. In the context of Nepal, many parents believe that quality of education in community colleges is higher than government based colleges. 
So majority of the students prefer to be enrolled in community colleges in spite of the higher tuition fees and other charges of these colleges. Thus, it is most important to analyze the college related institutional and noninstitutional direct private cost of education in community based colleges of Nepal.

\section{Review of related literature}

Unit cost in education is a useful guide for the educational planners and managers. They provide information on the actual cost involved in producing a graduate at any level of education. It gives an insight into the pattern of educational expenditures. The various cost concepts are relevant as these help governments to make choices and take varied decisions.

Cost of education indicates the amount of money spent to achieve education. It refers to the amount of money spent during a particular period to acquire education. Individual costs or private costs of education are those costs of education incurred by students or their parents as a whole. These concern individuals and families, and represent costs which the individuals and the families must bear in return for the education received (Aghenta, 1993, p. 90).

The cost of college for students includes more than the expenditures for tuition; it also includes forgone earnings. The earnings and experience given up to continue education are significant, possibly greater than the tuition that must be paid. According to National Center for Education Statistics of USA, if the earnings of high school graduates between the ages of 18 and 23 are relatively low, they are nevertheless high when compared to average tuition charges, particularly those at public institutions. Thus, falling labor market opportunities for high school graduates may have reduced the cost of enrolling in higher education as much as rising tuition has increased it (Alsalam, 1996, p. 18).

Mark Bray has completed a research entitled 'the private costs of public schooling: household and community financing of primary education in Cambodia' sponsored by UNICEF. This research has concluded that positive consequences of household and community financing can extend the quantity and improve the quality of education. Without the household and community inputs in Cambodia, some schools would have been unable to function at all. On the negative side, the most serious problems concern equity and access. Household and community financing maintains and exacerbates inequalities between regions, rural and urban areas, individual schools, and between socio-economic groups. Further, this study has 
highlighted that in most countries, community resourcing of education is less vigorous in urban than in rural areas. One positive feature in Cambodia is the high proportion of schools which are functioning school committees. These committees act as a bridge between teachers, parents and other members of communities, and play a major role in both institutional and broader development (Bray, 1999, p. 68).

Following a study done by UNESCO (2013), equity and quality are the two faces of the same "coin" of educational development. Evidence shows that inequitable system cannot be a quality education system, as illustrated by the analysis of the international assessment tests. A quality secondary education system should ensure access to education for the disadvantaged groups, by providing specific support in terms of public financing, scholarships, formula funding, supply of qualified professional staff, and provision of adequate materials and facilities (UNESCO, 2013, p. 44).

There exists numerous difficulties in determining educational costs, some of them include the problems such as: (i) Budgetary data are often inadequate for a detailed study of costs because they only cover the expenditures but not the real resource or opportunity costs, (ii) In most cases budgetary data only present the planned or provisional budget estimates rather than the actual expenditures, (iii) There is apparent confusion in distinguishing between recurrent and capital expenditure, (iv) The treatment of capital expenditure varies considerably from one study to another; and (v) There is lack of uniformity in the methodologies used in analyzing costs. There are many factors that may determine or affect educational costs. Tsang (1995) has categorized these factors into two: (a) factors that determine the total amount of resources devoted to education, and (b) factors that determine expenditures within education. Often, public expenditure represents a large portion of resources devoted to education. Generally, the costs incurred in imparting or acquiring education are mainly determined by the following factors (a) Educational demand, (b) Educational technologies, (c) Teacher salary structures, (d) Dropout and repeater rates, (e) Utilization rates, and (f) Market forces (Wachiye and Ejakait, 2014, p. 64).

Cost analysis in education provides useful guide to education planners on the actual cost involved in producing a graduate at any level of education. Indeed, it gives an insight into the pattern of educational expenditures. Cost analysis is often used to identify possible cost reduction. The need for cost reducing measures and more generally for policies towards cost effectiveness is necessary as the private cost of education is likely to be the 
lowest in municipal schools as the local government bears the entire cost of education and the highest in private-unaided schools (Khandagale and Pandya, 2014, p. 73-44).

Ismail and others (2016) had completed a research entitled 'analysis of private and social costs of education in Malaysia'. They had concluded that daily expenses appear to have contributed the most in terms of private costs of education for primary and secondary schools, while fees and cost of living are the major components at the tertiary level. The cost of private education for 17 years of schooling is almost 120,000 Malaysian Ringgit per student, while the social costs have increased to almost five-fold in the last decade. The financial resources of education loans or scholarships were insufficient to cover the cost. Thus, some students resort to taking up part-time jobs or seeking additional financial assistance from parents to bear the cost. Moreover, the cost of education for the first and second semesters is much higher than other semesters. This is due to the need to acquire basic longterm necessities such as laptop, printer, course materials and a variety of fees. Fees and living expenses are the main components of overall student expenditure. In fact, for city-campus universities, the cost of living is much higher (Ismail and others, 2016, p. 26).

\section{Research gap}

Aforementioned literatures have mainly focused on costs of education, categories of educational costs, and overall pattern of cost sharing in higher education. Similarly, some literatures have explained the concept of unit cost of education and linked it with facilities and achievement on the basis of students' and their parents' view. Likewise, other literatures have not particularly pointed out the cost sharing pattern in the case of community based colleges. But, nature of community based colleges is different from others like private and government-supported colleges. Community colleges are not profit oriented and their sources are student fee and community support as well as donor agencies' donation. Their management system is somehow matched with that of private colleges. In this context, I felt the need to see the situation of direct private investment/cost of education at Bachelor's level in community based colleges in Kathmandu valley of Nepal. It is the gap of knowledge for this study.

\section{Methodology}

This study is basically a quantitative inquiry which has used descriptive research design. It provides a general view, and guides us towards the 
characterization of circumstances and assessment of the existing status. Descriptive research attenpts to answer what, when, where, and how questions on the given situation or phenomenon, but not why questions (Nunan, 1992, p. 141). It is to obtain a snapshot of continuous situations and events at a single point of time. This research design uses wide variety of quantitative methods to investigate variables - whereby the researcher does not control or manipulate any of the variables, but only collects and assesses the information.

Nunan (ibid., p. 142) has presented the important procedures of descriptive research, which proceeds ahead through the steps of: defining objectives, identifying the target population, literature review, determining sample, identifying instruments, designing the procedures. In this study, I have selected a community based college from Kathmandu valley purposively; and 90 students from this college were sampled using simple random sampling procedure - including 30 from the stream of Humanities, 30 from Education and 30 from Management s.

Questionnaires and interview guidelines were the tools applied for data collection. Questionnaires were used to collect data from the college administration, Central Library, Dean's Office and the Office of the Controller of Examinations, TU. Likewise, interview guidelines were used for data collection from the selected students, college Principals, Deans, Controller and account officer of Central Library of TU. Filling in the questionnaire and face to face interview were used as the techniques of data collection. At first, I had visited the selected college, met college Principal, briefed about my aims, and requested him to give information. When he was ready to give information, I gave him the questionnaire form to fill-up, and I collected that form after a week. I had used the same technique to collect information from the Office of the Controller of Examinations, Dean's Office, and Central Library. Likewise, I met all the respondents, told them my aims, convinced them and conducted face to face interviews with different respondents. The collected data were then studied, presented in the tables, thenanalyzed descriptively and discussed.

\section{Result and discussion}

This section presents the analysis, interpretation and discussion of the results of study including the analysis of data collected from secondary sources. The presentation of the data and discussion of the results are divided into two different themes: institutional cost and non-institutional cost at Bachelor's level of education. 
Analysis of Direct Private Investment: The Case of Bachelor's Level...

\section{College related institutional cost}

It indicates those costs of education incurred by students in college which the students or their parents directly pay to college's cash counter in cash for different items, and they receive slip or bill. This research has included college related institutional direct cost of education, such as, admission fee (annual fee), tuition fee (monthly fee), transportation charge, term exam fee, educational tour charge, coaching fee, tuition fee, computer fee, name registration charge, thesis charge, character certificate charge, recommendation letter charge, campus stationery charge, identity card fee, library card fee, library late fine, college absent fine, term exam absent fine and practical exam fee. These are shown in table 1.

Table 1: College related institutional direct private cost, 2074 (In Rs)

\begin{tabular}{|c|c|c|c|c|c|c|c|}
\hline \multirow[t]{2}{*}{ Items } & \multicolumn{3}{|c|}{ Total at Bachelor's level } & \multicolumn{3}{|c|}{ Annual average } & \multirow{2}{*}{$\begin{array}{c}\text { Total annual } \\
\text { average at } \\
\text { Bachelor's } \\
\text { level }\end{array}$} \\
\hline & BA & B. Ed & BBS & BA & B. Ed & BBS & \\
\hline Annual/Admission fee & 28000 & 37000 & 37000 & 9333.33 & 9250 & 9250 & 9277.78 \\
\hline Tuition fee & 37800 & 50400 & 50400 & 12600 & 12600 & 12600 & 12600 \\
\hline Term exam fee & 2700 & 3600 & 3600 & 900 & 900 & 900 & 900 \\
\hline Character certificate & 1200 & 1200 & 1200 & 400 & 300 & 300 & 333.34 \\
\hline Recommendation letter & 50 & 50 & 50 & 16.67 & 12.5 & 12.5 & 13.89 \\
\hline Identity card charge & 150 & 200 & 200 & 50 & 50 & 50 & 50 \\
\hline Library card charge & 50 & 50 & 50 & 16.67 & 12.5 & 12.5 & 13.89 \\
\hline Term exam absent fine & 2250 & 3000 & 3000 & 750 & 750 & 750 & 750 \\
\hline Practical exam fee & 150 & 150 & 150 & 50 & 37.5 & 37.5 & 41.67 \\
\hline Teaching practice fee & - & 3000 & - & & 750 & & 750 \\
\hline Total & 72350 & 98650 & 95650 & - & - & - & - \\
\hline Annual average cost & 24116.7 & 4662.5 & 3912. & 116. & 1662.5 & 23912.5 & 24730.57 \\
\hline
\end{tabular}

(Source: Field study 2075)

Table 1 presents the charges on admission fee, tuition fee, term exam fee, character certificate charge, recommendation letter charge, identity and library card charge, term exam absent fine, practical exam fee, and teaching practice fee. The data presented here are explained in the sub-headings that follow.

a) Annual/admission fee: Students must pay certain amount of money for getting enrolled in the college. It is called the annual or admission fee. It is charged by college annually. The data in table 1 shows that each 
student has paid Rs. 10,000 for first year admission and Rs. 9,000 for every second, third and fourth year. The total annual/admission fee for three year Bachelor's level in the Faculty of Humanities (BA) is Rs. 28,000 and for four year Bachelor of Education (B.Ed) and Management (Bachelor of Business Studies, BBS) it is Rs. 37,000. Annual average admission fee is Rs. 9333.34 for BA and for B.Ed. and BBS it is Rs. 9250; and total annual average at Bachelor's level is Rs. 9277.78.

b) Tuition fee: Tuition fee is charged by college for instruction or other services. Besides public spending (by governments and other public bodies), private spending via tuition payments are the largest revenue sources for education institutions in some countries. The data in table 1 reveals that each student has paid Rs. 1050 per month and Rs. 12,600 per annum as tuition fee at Bachelor's level. Each student has paid total tuition fee Rs. 37,800 at BA and Rs. 50,400 at B. Ed and BBS. Per student annual average tuition fee is Rs. 12,600 at Bachelor's level of all faculties.

c) Term exam fee: The college sampled for study conducts the internal term-exam three times a year. For this purpose, the college charges Rs. 300 per term-exam and Rs. 900 annually (for three term-exam) to the students. Students of BA have paid in total Rs. 2700 as the term-exam fee; and students of B.Ed. and BBS have paid total term-exam fee Rs. 3600. Per student annual average term-exam fee is Rs. 900 at Bachelor's level of all faculties.

d) Character certificate charge: To obtain the character certificate, the students must pass the Bachelor's level. It is given by college to the students on the basis of their academic achievement and discipline maintained by them in college life. Only one time after completing the entire cycle of Bachelor's level, students pay some amount of money to get character certificate from college; but for it student must have been graduated. The data in table 1 reflects that college has charged Rs. 1200 from each student. This amount is same for the students of each faculty.

e) Recommendation letter charge: Recommendation letter is necessary for both types of students - first, for those who are studying now; and second, for those who have been graduated from the college. When students take it from the college, the college charges certain amount for this. Generally, students take it one time; and he/she uses it to fulfill several purposes. The data in table 1 shows that the college has charged only Rs. 50 from each student for this kind of letter. 
f) Identity and library card charge: College provides identity card to identify the students and gives library card to let them use library, charging some fee. The data of sampled college shows that they charge Rs. 50 for an identity card and Rs. 50 for a library card. Thus, in total, a student has paid Rs. 100 for these cards.

g) Term exam absent fine: The informants responded that the college conducts internal term-exam three times a year; and if any student became absent in any term-exam, s/he is charged Rs. 250 per-subject. If $\mathrm{s} /$ he did not appear in any of the subjects in a term exam, then $\mathrm{s} / \mathrm{he}$ would be charged Rs. $250 \times 5=$ Rs. 1250 (as there are five subjects). In this way, if a student did not appear any of the subjects in any of the term exams, then s/he would be charged Rs. 11250 for three-year Bachelor's course, and Rs. 15000 for four-year Bachelor's course. The data reveals that a student of three-year Bachelor's course has paid Rs. 2250 and a four year Bachelor's student has paid Rs. 3000 annually.

h) Practical exam fee: The data in table 1 reveals that each student has paid Rs. 150 for practical exam at Bachelor's level of Humanities, Education and Management faculties annually.

i) Teaching practice fee: Provision of teaching practice is only in Education faculty (not in BA and BBS courses). The information given in table 1 shows that each student of B.Ed. has paid Rs. 3000 for teaching practices at Bachelor's level.

\section{University related institutional cost}

It indicates the costs of education incurred by students at the university under such headings as university registration fee, board exam fee, exam form fee, exam centre fee, practical exam fee, service fee, teaching practice fee, thesis fee, university certificate (original certificate) fee, transcript fee, university recommendation fee, central library card fee, central library late fine, and central library clearance fee. These are shown in Table 2. 
Analysis of Direct Private Investment: The Case of Bachelor's Level...

Table 2: University related institutional direct private cost - 2074 (In Rs)

\begin{tabular}{|l|l|l|l|}
\hline Items & $\begin{array}{l}\text { Charge } \\
\text { fxed by } \\
\text { TU (in Rs) }\end{array}$ & $\begin{array}{l}\text { Number of } \\
\text { sample students } \\
\text { who paid it }\end{array}$ & $\begin{array}{l}\text { Total paid } \\
\text { amount (In } \\
\text { Rs) }\end{array}$ \\
\hline University registration fee & 500 & 90 & 45000 \\
\hline Board exam fee & 470 & $30 \times 3+60 \times 4$ & 155100 \\
\hline Exam form fee & 60 & $30 \times 3+60 \times 4$ & 19800 \\
\hline Exam centre fee & 100 & $30 \times 3+60 \times 4$ & 33000 \\
\hline Practical exam fee for one subject & 150 & 60 & 9000 \\
\hline $\begin{array}{l}\text { Practical exam fee for two or more } \\
\text { subjects }\end{array}$ & 250 & 30 & 7500 \\
\hline $\begin{array}{l}\text { Field work, term paper and project } \\
\text { work }\end{array}$ & 275 & 60 & 16500 \\
\hline Service fee & 250 & 90 & 22500 \\
\hline Teaching practice fee forOCE & 50 & 30 & 1500 \\
\hline $\begin{array}{l}\text { Teaching practice fee for Dean } \\
\text { Office }\end{array}$ & 200 & 30 & 6000 \\
\hline University certificate fee & 1700 & 90 & 153000 \\
\hline Transcript fee & 450 & 90 & 40500 \\
\hline University recommendation fee & 1000 & 20 & 20000 \\
\hline Central library clearance fee & 100 & 90 & 9000 \\
\hline Annual average cost per student $=5982.23$ & & \\
\hline
\end{tabular}

(Source: Field study, 2075) OCE: Office of the Controller of Examinations

Table 2 shows the university related institutional costs at Bachelor's level. It was found that students have compulsion to pay the university registration fee, board exam fee, exam form fee, exam centre fee, TU service fee, university certificate (original certificate) fee and transcript fee. Similarly, it was also found that each student has to pay the central library clearance fee which is Rs. 100. Students of three year programme (BA) have to pay three times and students of four year programme (B.Ed. and BBS) have to pay the board exam, exam form and exam centre fee four times during the whole academic sessions of Bachelor's level programme. The students have to pay Rs. 1,55,100 for board exam, Rs. 19,800 for exam form and Rs. 33,000 for exam centre.

As reported by 60 students (among 90 of them), they have paid Rs. 9,000 as the practical fee for one subject. In the same way, 30 students have paid Rs. 7,500 as the practical fee for two or more subjects. Regarding the fee for 
Field work, term paper and project work, 60 students paid Rs. 16,500. Only 30 students of B.Ed. have paid Rs. 6,000 to the Dean's Office of TU as the teaching practice fee, and Rs. 1,500 was paid to Office of the Controller of Examinations. Out of 90 students, 20 have taken university recommendation letter, so they have paid Rs. 20,000 to TU.

On the basis of fourteen different titles and total amount presented in table 1, it is found that the average university related institutional direct cost per student at Bachelor's level of Tribhuvan University (from first to last year) is Rs. 5982.23.

\section{Institutional costs}

It refers to those costs of education which are paid by students to the college and university. Therefore, it is summation of college related institutional cost and university related institutional cost, as shown in table 3.

Table 3: Institutional direct private cost of education - 2074 (in Rs)

\begin{tabular}{|l|l|l|l|}
\hline Details & $\begin{array}{l}\text { Annual average } \\
\text { college related } \\
\text { institutional cost }\end{array}$ & $\begin{array}{l}\text { Annual average } \\
\text { university related } \\
\text { institutional cost }\end{array}$ & $\begin{array}{l}\text { Total annual } \\
\text { average } \\
\text { institutional cost }\end{array}$ \\
\hline Amount & 24730.57 & 5982.23 & 30712.80 \\
\hline
\end{tabular}

(Source: Table 1 and Table 2 presented above)

Table 3 shows the summation of annual average college related institutional cost and annual average university related institutional cost of education at Bachelor's level, which is Rs. 30712.80. The annual average college related institutional cost is Rs. 24730.57 and annual average university related institutional cost is Rs. 5982.23 for Bachelor's level.

\section{Non-institutional costs}

It indicates the costs of education incurred by students within and outside college. Students or their parents directly pay to the shops in cash for various items; and they receive slip or bill. This research has included education related non-institutional direct private cost in titles such as textbooks, reference books, all types of stationery, college bag, college uniform (tie, belt and dress), shoes (uniform shoes and sports shoes), college coat, sweater and jacket, college sports uniform, college tiffin, co-curricular activities, photocopy and printing of study materials, e-mail and internet, computer as a study material, college transportation, coaching and tuition (outside the college), student welfare, educational donation, material/equipment support, picnic program, field trip 
and educational tour. These titles are explained on the basis of gender, parent's occupation, religion and faculties. It is presented in table 4.

Table 4: Non-institutional direct private cost of education at Bachelor's level $-2075$

\begin{tabular}{|l|c|c|c|c|c|c|}
\hline Gender & $\begin{array}{c}\text { No. of } \\
\text { students }\end{array}$ & $\begin{array}{l}\text { Total cost } \\
\text { (in Rs) }\end{array}$ & $\%$ & $\begin{array}{l}\text { Average cost } \\
\text { (in Rs) }\end{array}$ & $\begin{array}{l}\text { Per-student cost of } \\
\text { BA (in Rs) }\end{array}$ & $\begin{array}{l}\text { Per-student cost } \\
\text { of B.Ed. and } \\
\text { BBS (in Rs) }\end{array}$ \\
\hline Boys & 45 & 2205607 & 52.80 & 49013.48 & 147040.44 & 196053.92 \\
\hline Girls & 45 & 1971441 & 47.20 & 43809.79 & 131429.37 & 175239.16 \\
\hline Total & 90 & 4177047 & 100 & 46411.63 & 139234.63 & 185646.52 \\
\hline
\end{tabular}

Source: Field study, 2075

On average, it was found that a student has expensed Rs. 46411.63 as noninstitutional direct private cost in a year. Similarly, a student has expensed Rs. $46411.63 \times 3=$ Rs. 139234.89 for three year BA, and Rs. $46411.63 \times 4=$ Rs. 185646.52 for four year B.Ed. and BBS. Data shows that the cost for boys and girls is distinct. The annual average non-institutional private direct cost for a boy student is 49013.48; and he expenses Rs. $49013.48 \times 3=147040.44$ in three year BA and Rs. $49013.48 \times 4=196053.92$ in four year B.Ed. and BBS. Similarly, the annual average non-institutional private direct cost of a girl student is 43809.79 , and she expenses Rs. $43809.79 \times 3=131429.37$ in three year BA and Rs. $43809.79 \times 4=175239.16$ in four year B.Ed. and BBS.

\section{Institutional and non-institutional costs: A comparison}

Institutional cost includes the costs of education required to be paid by students to the college and university. Students or their parents pay it directly to the college and university's cash counter. But, non-institutional cost includes the costs incurred by students within and outside college and university, which are unofficial expenses. The amounts of both institutional and non-institutional cost are presented in table 5 .

Table 5: Institutional and non-institutional direct private cost - 2074 (in Rs)

\begin{tabular}{|l|l|l|l|}
\hline Details & $\begin{array}{l}\text { Annual average } \\
\text { institutional cost at } \\
\text { Bachelor's level }\end{array}$ & $\begin{array}{l}\text { Annual average non- } \\
\text { institutional cost at } \\
\text { Bachelor's level }\end{array}$ & $\begin{array}{l}\text { Total annual average direct } \\
\text { private cost of education at } \\
\text { Bachelor's level }\end{array}$ \\
\hline Amount & 30712.80 & 46411.63 & 77124.43 \\
\hline
\end{tabular}

(Source: Table 3 and Table 4) 
Table 5 shows that the annual average direct private cost of education for Bachelor's level, in total, is Rs. 77124.43. On average, the annual institutional cost and annual non-institutional cost for Bachelor's level are Rs. 30712.80 and Rs. 46411.63 respectively.

\section{Findings and conclusion}

From the data presented and described above, it was found that each student has paid Rs. 9333.34 as the annual average admission fee for BA and Rs. 9250 for B.Ed. and BBS, and Rs. 9277.78 for Bachelor's level of all faculties. A student has paid tuition fee Rs. 1050 per month, Rs. 12,600 per year, Rs. 37,800 for three-years of BA, and Rs. 50,400 for four-year of B.Ed. and BBS. Per student annual average tuition fee is Rs. 12,600 for Bachelor's level of all faculties. Similarly, a student has paid Rs. 300 per term-exam, Rs. 900 per year, Rs. 2700 for BA and Rs. 3600 for B.Ed and BBS. College has charged Rs. 1200 for character certificate, Rs. 50 for a recommendation letter, Rs. 50 for identity card, Rs. 50 for library card and Rs. 250 for absence in term exam. Students of B.Ed. have paid Rs. 2,000 for teaching practice to the college.

In case of university related institutional direct private cost, a student has paid Rs. 500 for name registration in university, Rs. 470 for board exam, Rs. 60 for exam centre, Rs. 150-250 for practical exam, Rs. 275 for field work, term paper and project work, Rs. 250 for TU service, Rs. 250 for teaching practice, Rs. 1700 for university certificate, Rs. 450 for transcript, Rs. 1000 for recommendation letter and Rs. 100 for central library clearance.

Per student average college related institutional unit cost is Rs. 24730.57, university related institutional cost is Rs. 5982.23, and total annual institutional unit cost is Rs. 30712.80 at Bachelor's level of community based college in the capital city of Nepal. Likewise, it was found that a student has expensed Rs. 46411.63 as non-institutional direct private cost in a year. Total annual average direct private cost of education (institutional plus non-institutional) for Bachelor's level is Rs. 77124.43.

Based on these findings, it is concluded that these programmes seem expensive to those people who are living below the poverty line in Nepal. In the country, absolute poor people are $21.6 \%$, and multi-dimensional poor people are 28.6\% (Ministry of Finance, 2075); but nominal income of the poorest 20 percent people is Rs. 15888 each annually and poverty line income is Rs. 19262 annually (CBS, 2011). Therefore, these people's 
children cannot afford to study in community based college in Nepal, particularly in the capital city of Nepal.

This finding would be useful for those people whose income has remained middle level or lower than it, because they will compare the cost of community based colleges with their income level, and only then they will take decision about enrolment of their children. Likewise, it can be recommended that further studies can cover those parts of educational costs which are not included in this study - such as public direct and indirect costs, and private indirect costs of education.

\section{References}

Aghenta, J.A. (1993). Principles and practices of educational planning (focus on the developing countries). Benin: Nigerian Society for Educational planning (NSEP).

Akpotu, Nelson Ejiro. (2008). Social cost analysis of secondary education in South West Nigeria (1996-2001). Research Journal of Social Science. 16(1), pp. 27-33. Retrieved from http://citeseerx.ist.psu.edu/viewdoc/ download?doi=10.1.1.597.1894andrep=rep1andtype $=$ pdf

Alsalam, Nabeel. (1996). The cost of higher education. America: National center for education statistics, U.S. Department of Education, Office of Educational Research and Improvement. Retrieved from https://nces.ed.gov/pubs/96769.pdf.

Babalolaj. B. (1995). Educational costs and financial analysis. Ibadan: Department of educational management, University of Ibadan. Retrieved from https://www.academia.edu/22993339/Educational Costs_and_Finanacial_Analysis.

Bray, Mark. (1999). The private costs of public schooling: Household and community financing of primary education in Cambodia. Paris: International Institute for Educational Planning, UNESCO.

CBS (2011). Nepal living standards survey- 2010/11 (vol. II). Kathmandu: Central Bureau of Statistics, National Planning Commission Secretariat, Government of Nepal.

Ismail, Ramlee; Awang, Marinah; and Noor, Mohd Asri Mohd. (2016). Analysis of private and social costs of education in Malaysia: An Overview. International Journal of Academic Research in Business and Social Sciences, 6(11), 24-37. Retrieved from http://hrmars.com/ 
hrmars_papers/Analysis_of_Private_and_Social_Costs_of_Education_i n_Malaysia_An_Overview.pdf.

Khandagale, Vidyanand S.; and Pandya, Shefali (2014). Private cost of education and academic achievement of students: An analysis by school types. IOSR Journal of Humanities and Social Science (IOSR-JHSS). 19(2), 39-43. Retrieved from https://www.researchgate.net/ profile/ Vidyanand_Khandagale/publication/277667770_Private_Cost_of_Educ ation_and_Academic_Achievement_of_Students_An_Analysis.pdf.

Lugaz, Candy; and Grauwe, Anton Drauwe. (2016). Improving school financing: The use and usefulness of school grants (Lessons from East Asia and the Pacific). Paris: International Institute for Educational Planning, United Nations Educational, Scientific, and Cultural Organization (UNESCO). Retrieved from https://unesdoc.unesco.org/ ark:/48223/pf0000246372.

Ministry of Finance (2075). Economic survey 2074/75. Kathmandu: Ministry of Finance, Government of Nepal.

Nunan, David. (1992). Research methods in language learning. Cambridge: Cambridge University Press. Retrieved: https://www.academia. edu/31150928/_David_Nunan_Research_Methods_in_Language_Learn ing.

Psacharopoulos, George and Woodhall, Maureen. (1995). Education for development (An analysis of investment choices). Washington DC: Oxford University Press.

Tsang, Mun C. (1995). Private and public costs of schooling in developing nations. International Encyclopedia of Economics of Education (2nd ed.). Martin Carnoy (Ed.). United Kingdom: Pergamon.

UNESCO. (2013). Financing of secondary education in the Asia-Pacific Region - Synthesis Paper (Education Policy Research Series Discussion Document No.4). Bangkok: Education Policy and Reform Unit, UNESCO. Retrieved from https://www.researchgate.net/ publication/ 276271715_Financing_Secondary_Education_in_Asia_and_Pacific.

Wachiye, Herman J. and Ejakait, Epari (2014). Understanding costs in education. Journal of Research Signpost. NA: 63-73. Strategic Organizational, Planning and Management. Retrieved from https://www.trnres.com/ebook.pdf. 